\title{
Carbon and Nitrogen Mineralization of a Plant Residue Amended Soil: The Effect of Salinity Stress
}

\author{
B. C. Walpola* and K. K. I. U. Arunakumara
}

Department of Soil Science, Faculty of Agriculture, University of Ruhuna, Mapalana, Kamburupitiya, Sri Lanka.

\begin{abstract}
A factorial combination of saline and non-saline soil with three residue types (Sesbania grandiflora, Caliandra calothyrsus and Gliricidia maculata leaves) was used in laboratory incubation. The $\mathrm{CO}_{2}-\mathrm{C}$ content of plant residue amended soils was found to be increased steadily during the first two weeks of incubation followed by gradual reduction as incubation progressed. Under non-saline condition $(E C=0.97$ $\mathrm{dS} / \mathrm{m})$, the highest cumulative $\mathrm{CO}_{2}-\mathrm{C}$ content $(1551 \mathrm{mg} / \mathrm{kg}$ soil) was observed in Caliandra amended soil, followed by Sesbania (1161 $\mathrm{mg} / \mathrm{kg}$ soil) and Gliricidia (1042 $\mathrm{mg} / \mathrm{kg}$ soil). The higher biodegradability of Caliandra leaves induced by the higher C content compared to the other residues. The $\mathrm{CO}_{2}-\mathrm{C}$ evolved under saline condition $(E C=18.2 \mathrm{dS} / \mathrm{m})$, ranged from $313 \mathrm{mg} / \mathrm{kg}$ (control) to $905 \mathrm{CO} 2-\mathrm{C} \mathrm{mg} / \mathrm{kg}$ (Caliandra amended) soils. Sesbania amended non-saline soil showed the highest $\left(227 \mathrm{mg} / \mathrm{kg}\right.$ soil) and rapid release of $\mathrm{NH}_{4}{ }^{+}-\mathrm{N}$, followed

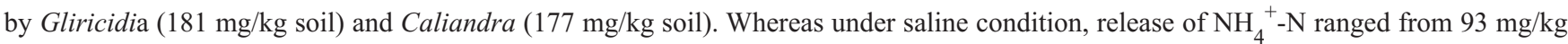
(control) to $183 \mathrm{mg} / \mathrm{kg}$ (Sesbania amended). Though treatment behavior pattern of $\mathrm{NO}_{3}{ }^{-}-\mathrm{N}$ was similar to that of $\mathrm{NH}_{4}{ }^{+}-\mathrm{N}$ throughout the incubation, saline soil showed significantly $(\mathrm{P} \leq 0.05)$ low $\mathrm{NH}_{4}{ }^{+}-\mathrm{N}$ and $\mathrm{NO}_{3}{ }^{-}-\mathrm{N}$ contents compared to non-saline soil.
\end{abstract}

Key words: Soil quality, Plant residues, Carbon and nitrogen mineralization, Salinity stres

\section{Introduction}

Soil salinity, one of the key contributors to land degradation (Al Yassin, 2005), exits in topographically low lands near the sea where intrusion of seawater to the aquifer is inevitable and in irrigated agricultural fields (Okur, 2002). The salt caused both by natural and cultural effects on soil can be of chemical, physical and biological origin (Okur, 2002). The affected saline soils are characterized by high concentrations of soluble salts and low organic matter and nitrogen content (Asmalodhi et al., 2009). As it provides unfavorable condition for plant growth resulting in poor crop yield (Anjum et $a l ., 2005)$, reclamation is needed to ensure sustained crop production in these affected soils. Reclamation or improvement of these soils can basically be accomplished in many ways, the best dictated by local conditions and available resources (Elsharawy et al., 2008).

As the negative effects of salinisation are intensified by the low levels of soil organic matter (Muhammad et al., 2005), addition of organic materials was found to be a sound strategy for reclamation of these soils (Garcia, 2000). Different organic materials such as plant residues, animal manure or sewage sludge are being used as soil amendments and a source of nutrients for improving the soil quality. Despite plant residues can influence soil organic matter depending on their quantity and biodegradability (Dick and Gregorich, 2004), mineralization of nutrients from the added organic amendments can widely be varied (Rowell et al., 2001; Nakhone and Tabatabai, 2008). Salinisation has been identified as one of the most stressing environmental conditions for soil microorganisms (Sardinha et al., 2003), thus nutrient mineralization of such soil could be affected by the high concentrations of soluble salts. Moreover, release of inorganic forms of N, P and other organically-bound nutrients in soil is functionally associated with carbon mineralization (Mafongoya et al., 2000) hence, is affected by the salinity stress that inhibits the mineralization of organic materials in soil. The effects of biochemical composition of organic amendments on their decomposition kinetics have extensively been investigated (Thuriès et al., 2002). Moreover, several microbiological studies such as soil respiration and microbial biomass under saline conditions have also been reported (Okur, 2002). However, interaction between plant residue quality and salinity affecting carbon and nitrogen mineralization/immobilization is not well understood (Nourbakhsh and Hossein, 2006). The effects of salinity on soil biological processes often showed contradictory results (Vanessa et al.,

*Corresponding author. E-mail:bcwalpola@soil.ruh.ac.lk 
2004). Therefore, the objectives of this study were to investigate the effects of salinity on carbon and nitrogen mineralization of a plant residue amended soil.

\section{Materials and Methods}

\section{Soil characteristics and sampling}

Soil samples were collected in February, 2009 from randomly selected several locations along the coastal belt of the Madiha East GS Division of Matara, Southern Sri Lanka to represent saline soils. Non-saline soil samples were also collected from the same GS Division, but approximately 1000 $\mathrm{m}$ away from the sea. After removing the surface litter, soil samples were taken from $0-15 \mathrm{~cm}$ depth of the soil profile using an auger. They were transported to the laboratory in poly bags and stored at $4^{\circ} \mathrm{C}$ prior to analysis. Analytically grade chemicals without further purification were used throughout the experiment. The soil used in this study belongs to Red Yellow Podzolic great soil group and is classified as Hapludults according to the USDA soil taxonomy (Mapa et al., 1999). The physico-chemical characteristics of the soil were determined prior to the incubation using standard methods (Table I). A digital pH meter (model 868) was

Table I: Initial physico-chemical properties of saline and non-saline soil of the experimental field

\begin{tabular}{|c|c|c|}
\hline Property & Non saline soil & Saline soil \\
\hline Soil texture & $\begin{array}{c}\text { Sand - } 84 \% \\
\text { Silt - } 12 \% \\
\text { Clay - } 04 \%\end{array}$ & $\begin{array}{c}\text { Sand }-81 \% \\
\text { Silt - } 08 \% \\
\text { Clay - } 11 \%\end{array}$ \\
\hline $\begin{array}{l}\text { Bulk density } \\
\left(\mathrm{g} / \mathrm{cm}^{3}\right)\end{array}$ & 1.23 & 1.25 \\
\hline Soil pH & 6.3 & 8.04 \\
\hline $\mathrm{EC}(\mathrm{dS} / \mathrm{m})$ & 18.2 & 0.97 \\
\hline Organic C (\%) & 1.06 & 0.9 \\
\hline Total N (\%) & 0.13 & 0.3 \\
\hline Borax P (mg/kg of soil) & 96.3 & 230 \\
\hline $\begin{array}{l}\text { Exchangeable } \mathrm{K} \\
\text { (mg/kg of soil) }\end{array}$ & 175 & 110 \\
\hline
\end{tabular}

used in measuring soil $\mathrm{pH}$ and $\mathrm{EC}$ readings were measured in suspension of $\mathrm{H}_{2} \mathrm{O}(1: 2)$ by conductivity meter (CC-317). Micro Kjeldhal method (McGill and Figueiredo, 1990) was applied to measure total nitrogen content and soil $\mathrm{P}$ was extracted according to borax method (Dick and Tabatabai, 1977) and determined using a spectrophotometer (UV 2102). Exchangeable K (Blackmore et al., 1987) was determined using an atomic absorption spectrophotometer
(PGENERAL, TAS-986) and wet oxidation method (Tiessen and Moir, 1993) was applied to determine soil organic matter content. Soil texture was determined with the Sedimentation and Decantation method. All the chemicals were analytically graded and used without further purification. De-ionized water taken from a Millipore Milli-Q system was used throughout the experiments. All measurements of weight were performed with a digital balance (Sartorins, BS 210 S). The experiment was conducted at the Department of Soil Science, Faculty of Agriculture, University of Ruhuna, Mapalana, Kamburupitiya, Sri Lanka.

\section{Plant residue characteristics}

Fully matured healthy leaves of Sesbania grandiflora, Caliandra calothyrsus and Gliricidia maculata were collected from the research farm of the Faculty of Agriculture, University of Ruhuna. They were washed with running tap water, rinsed three times in distilled water and oven dried at $50^{\circ} \mathrm{C}$ for three days. Plant residues were then grounded and passed through a $1-\mathrm{mm}$ sieve and kept in glass sealed containers until analysis and/or incubation was performed. Organic C content of the leaves was determined using wet digestion procedures (Nelson and Sommers, 1982) and Kjeldahl digestion and distillation method (Bremner and Mulvaney, 1982) was used in determining the total $\mathrm{N}$ content (Table II).

Table II: Carbon and nitrogen content the leaves

\begin{tabular}{l|c|c}
\hline Species & C (\%) & N (\%) \\
\hline Sesbania grandiflora & 40.62 & 4.93 \\
Caliandra calothyrsus & 42.57 & 3.85 \\
Gliricidia maculata & 39.44 & 4.48 \\
\hline
\end{tabular}

Homogeneously mixed air dried $100 \mathrm{~g}$ of soil samples (both saline and non-saline) were placed in cleaned glass bottles. The soils in bottles were watered to adjust the moisture content to $50 \%$ of the field capacity (dry basis) and kept in dark for two weeks prior to addition of plant residues. The moisture content of the soils was monitored daily in order to make sure the sufficient moisture in the bottles. After twoweek pre-incubation period, the glass bottles were opened and $235 \mathrm{mg}$ of leaf material were mixed separately with the soil. The application rate was 5 tons per hectare, on the assumption that top $15 \mathrm{~cm}$ of an area of 1 ha contains 2.13 $\mathrm{X} 10^{9} \mathrm{~kg}$ soil (soil bulk density $1.42 \mathrm{~g} / \mathrm{cm}^{3}$ ). Soil samples without being amended by plant residue were used as control. The treated soil samples along with the controls were 
incubated in the dark at room temperature $\left(25 \pm 1^{\circ} \mathrm{C}\right)$. Constant moisture content of the soil was maintained throughout the incubation period.

\section{Carbon mineralization}

Soil samples were placed in gas-tight glass containers along with a vial containing $10 \mathrm{ml}$ of $1 \mathrm{M} \mathrm{NaOH}$ to trap $\mathrm{CO}_{2}$ and a vial of water to maintain humidity. Soil was incubated at room temperature $\left(25^{\circ} \mathrm{C}\right)$ in the dark and $\mathrm{NaOH}$ traps were replaced at 2, 5, 7, 14, 21, 28, 35, 42, 49, 56 and 70 days after the treatment. Unreacted alkali in the $\mathrm{NaOH}$ traps was titrated with $0.5 \mathrm{M} \mathrm{HCl}$ to determine $\mathrm{CO}_{2}-\mathrm{C}$ released from the soil (Alef, 1995).

\section{Nitrogen mineralization}

Nitrogen mineralization was determined in terms of inorganic $\mathrm{N}\left(\mathrm{NH}_{4}{ }^{+}-\mathrm{N}\right.$ and $\left.\mathrm{NO}_{3}{ }^{-}-\mathrm{N}\right)$ concentration of soil extracted at $2,5,7,14,21,28,35,42,49,56$ and 70 days after incubation. Samples containing $10 \mathrm{~g}$ soil were extracted using 30 $\mathrm{ml}$ of $2 \mathrm{M} \mathrm{KCl}$ and used to determine $\mathrm{NH}_{4}{ }^{+}-\mathrm{N}$ and $\mathrm{NO}_{3}{ }^{-}-\mathrm{N}$ respectively according to Berthelot reaction (Searle, 1984)
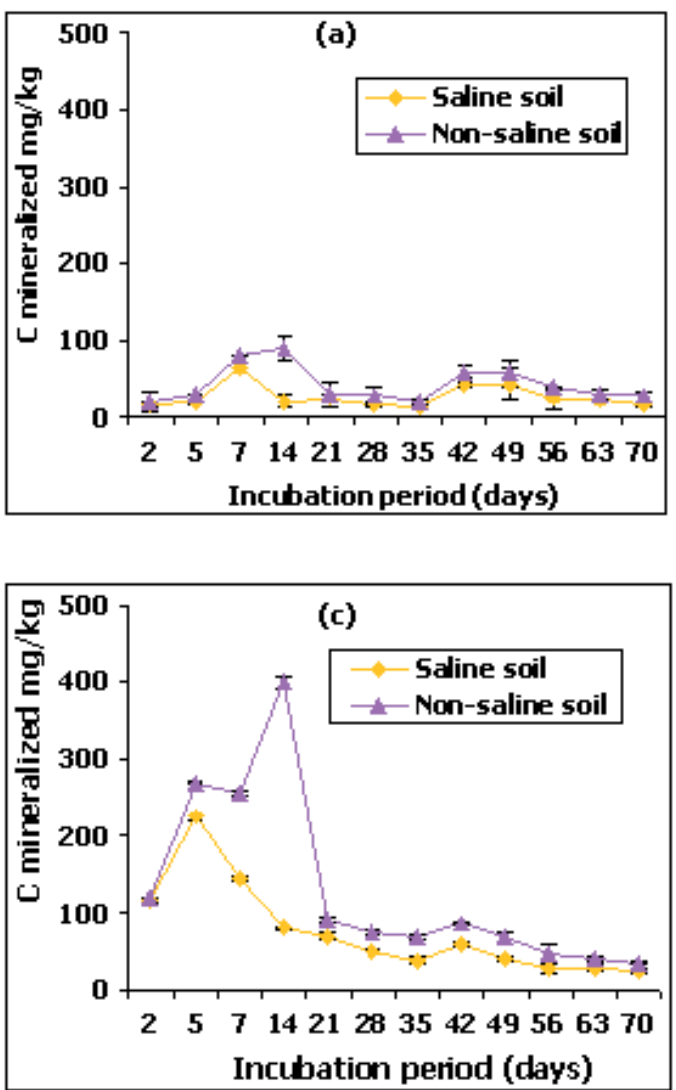

and sodium salicylate yellow color method (Bremner and Mulvaney, 1982).

\section{Statistical analysis}

Data generated were subjected to analysis of variance (ANOVA) for a Completely Randomized Design (CRD) with four replicates using SAS software (SAS Institute, 1988). Least significant difference at $P \leq 0.05$ was used to separate the means.

\section{Results and Discussion}

Changes in evolved $\mathrm{CO}_{2}-\mathrm{C}$ content from the saline $(E C=$ $18.2 \mathrm{dS} / \mathrm{m})$ and non-saline $(E C=0.97 \mathrm{dS} / \mathrm{m})$ soils during 10 week period of incubation are depicted in Figure 1. Three residue types amended to the soil resulted in different rates of $\mathrm{CO}_{2}$ evolution. Under non-saline condition, the highest $\mathrm{CO}_{2}-\mathrm{C}$ content was observed in the soil amended with Caliandra $(1551 \mathrm{mg} / \mathrm{kg}$ soil) residues followed by Sesbania $(1161 \mathrm{mg} / \mathrm{kg}$ soil) and Gliricidia $(1042 \mathrm{mg} / \mathrm{kg}$ soil) residues. The $\mathrm{C}$ mineralization from saline soil was significantly $(\mathrm{P} \leq$ $0.05)$ lesser than that of non-saline soil in all the treatments
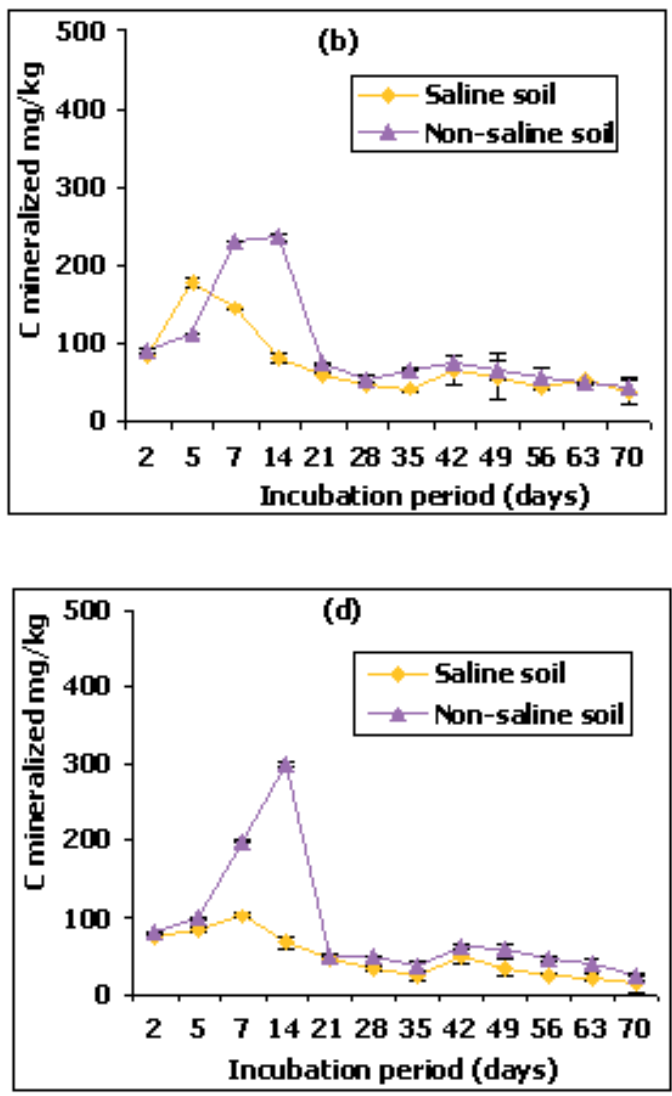

Fig. 1: Carbon mineralization of non-saline and saline soil amended with different plant residues. (a), (b), (c) and (d) respectively represent the control (without plant residues), Sesbania, Caliandra and Gliricidia amended soils. Values are the means $(n=4) \pm$ standard deviation 
irrespectively the residue type. Under saline condition, the evolved $\mathrm{CO}_{2}-\mathrm{C}$ content ranged from $313 \mathrm{mg} / \mathrm{kg}$ (control) to $905 \mathrm{mg} / \mathrm{kg}$ (Caliandra residue-amended soil). The greater amounts of $\mathrm{CO}_{2}$ produced in Caliandra residue treated soils can be attributed to the higher biodegradability of Caliandra leaves induced by higher $\mathrm{C}$ content compared to the other residues. This suggests that the readily decomposable fractions of organic $\mathrm{C}$ in Caliandra leaves are greater than those in Sesbania and Gliricidia leaves. The soil salinity caused to reduce the rates of $\mathrm{CO}_{2}$ evolution by 71.38, 28.57 and 81.51 $\%$ respectively in Caliandra, Sesbania and Gliricidia residue amended soils which is in agreement with Pathak and Rao (1998) who also reported a reduction of C mineralization in Sesbania cannabina treated saline soil. The reduction may be due to the addition of organic material which, in the short term, could provide additional substrates for the microbial population, resulting high osmotic and $\mathrm{pH}$ stress on the microorganisms as reported by Pathak and Rao (1998). The increasing salinity is also likely to be an osmotic stress retarding the activity of the microbial community (Galinski, 1995; Oren, 1999). Osmoregulation becomes a problem and the hypertonic environment tends to dehydrate the microorganisms. Specific ion toxicities (such as $\mathrm{Na}^{+}$and $\mathrm{Cl}^{-}$) may also tend to inhibit microbial growth in saline soils (Zahran, 1997) resulting poor $C$ mineralization. The ameliorative influence of Sesbania cannabina residues on $\mathrm{CO}_{2}$ evolution, microbial biomass, dehydrogenase and urease activities of salt-affected soils also has been reported by Rao and Pathak (1996).

In contrast, the cumulative $\mathrm{CO}_{2}-\mathrm{C}$ content of the control was about 33, 44 and $49 \%$ lower than that of Caliandra, Sesbania and Gliricidia residue amended soils under nonsaline condition. The comparative reductions under saline condition were 34, 35 and $54 \%$ respectively for Caliandra, Sesbania and Gliricidia treated soils. Results further revealed that except Caliandra and Sesbania treated saline soils, the cumulative $\mathrm{CO}_{2}$-C content of all the other treatments were significantly $(\mathrm{P} \leq 0.05)$ different (Figure. 2$)$.

Results revealed that the $\mathrm{N}$ mineralization of the soil was a function of the quality of plant residue amended to the soil.
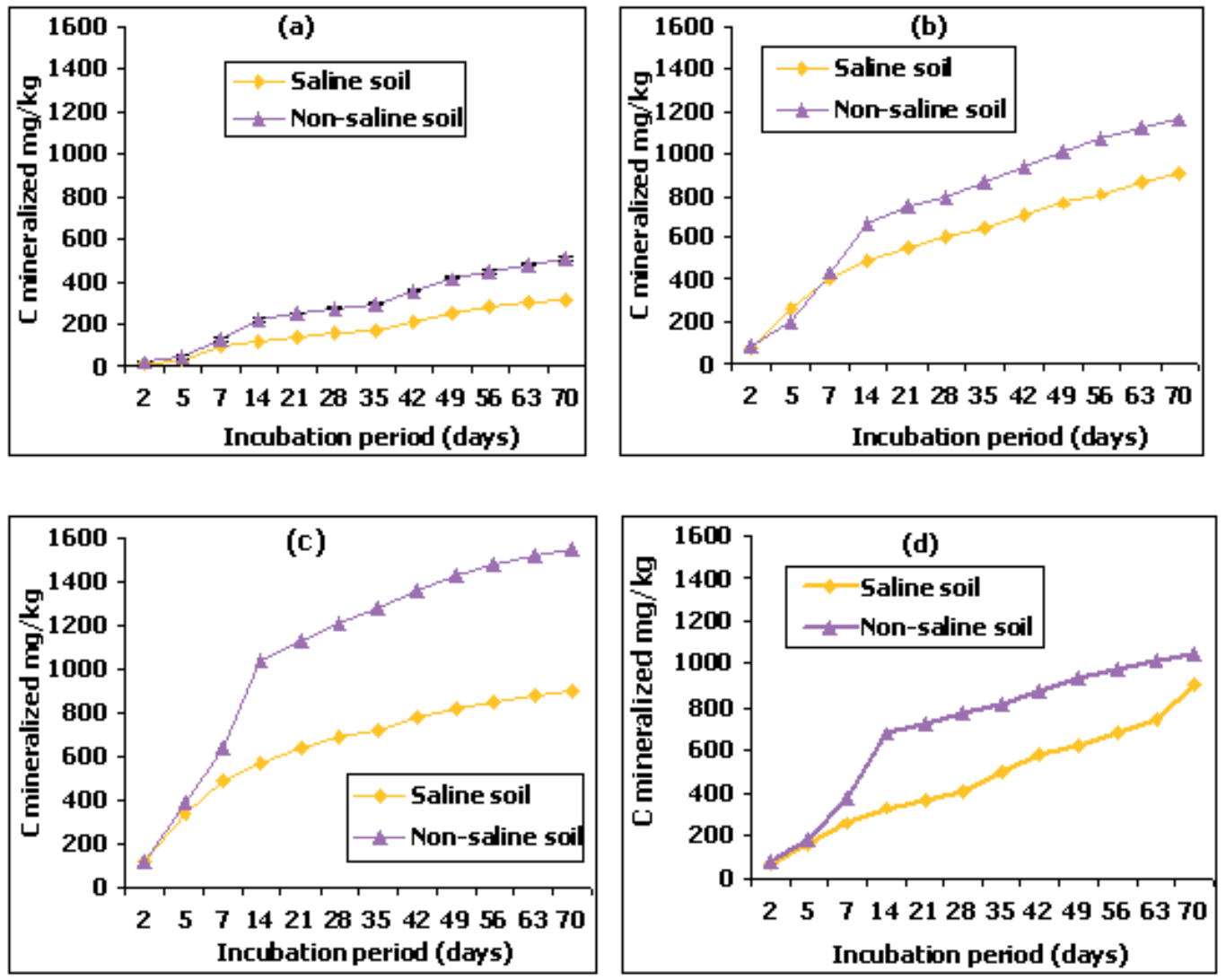

Fig. 2: Cumulative $C$ mineralization of the non-saline and saline soil amended with different plant residues. (a), (b), (c) and (d) respectively represent the control (without plant residues), Sesbania, Caliandra and Gliricidia amended soils. Values are the means $(n=4) \pm$ standard deviation 
As shown in Figure 3, no significant $(\mathrm{P} \leq 0.05)$ differences were found among three different residue types. However, released $\mathrm{NH}_{4}{ }^{+}-\mathrm{N}$ content from saline soil was found to be significantly $(\mathrm{P} \leq 0.05)$ lower than that of in non-saline soils throughout the incubation period. Results further revealed that three plant residues applied to the soil resulted in different rates of $\mathrm{NH}_{4}{ }^{+}-\mathrm{N}$ evolution irrespectively the type of soil. Despite the slow $\mathrm{NH}_{4}{ }^{+}-\mathrm{N}$ released during the first week of incubation, a progressive increased in $\mathrm{NH}_{4}{ }^{+}-\mathrm{N}$ content of all the treatments was observed as incubation proceeded. The $\mathrm{NH}_{4}{ }^{+}-\mathrm{N}$ content released during the period between 28 DAI to $35 \mathrm{DAI}$ was higher than the rest of the incubation period for all plant residue amended non-saline soils. However the control reached to the peak $\mathrm{NH}_{4}{ }^{+}-\mathrm{N}$ content at $21 \mathrm{DAI}$ and 5 DAI for non saline and saline soils respectively. After 35 days, a decreasing trend of available $\mathrm{NH}_{4}{ }^{+} \mathrm{N}$ in the non- saline soil was observed in all the treatments. Though comparatively lower available $\mathrm{NH}_{4}{ }^{+}-\mathrm{N}$ content was observed in plant residue amended saline soils, no distinguish fluctuation was observed throughout the incubation period.

A progressive increased in $\mathrm{NO}_{3}{ }^{-}-\mathrm{N}$ contents in both soils for all the treatments including control were found throughout the incubation period as shown in Figure 4. However, irrespectively the treatments, $\mathrm{NO}_{3}{ }^{-}-\mathrm{N}$ content of non-saline soil was found to be higher than that of saline soil. Sesbania has released higher $\mathrm{NO}_{3}{ }^{-}-\mathrm{N}$ contents at every stage of the incubation compared to control and other plant residues. This may be attributed to high quality nitrogen constituents and low protein binding material of Sesbania leaves as pointed out by Robertson and Morgan (1995) who discussed the importance of quality of carbon and nitrogen source in the
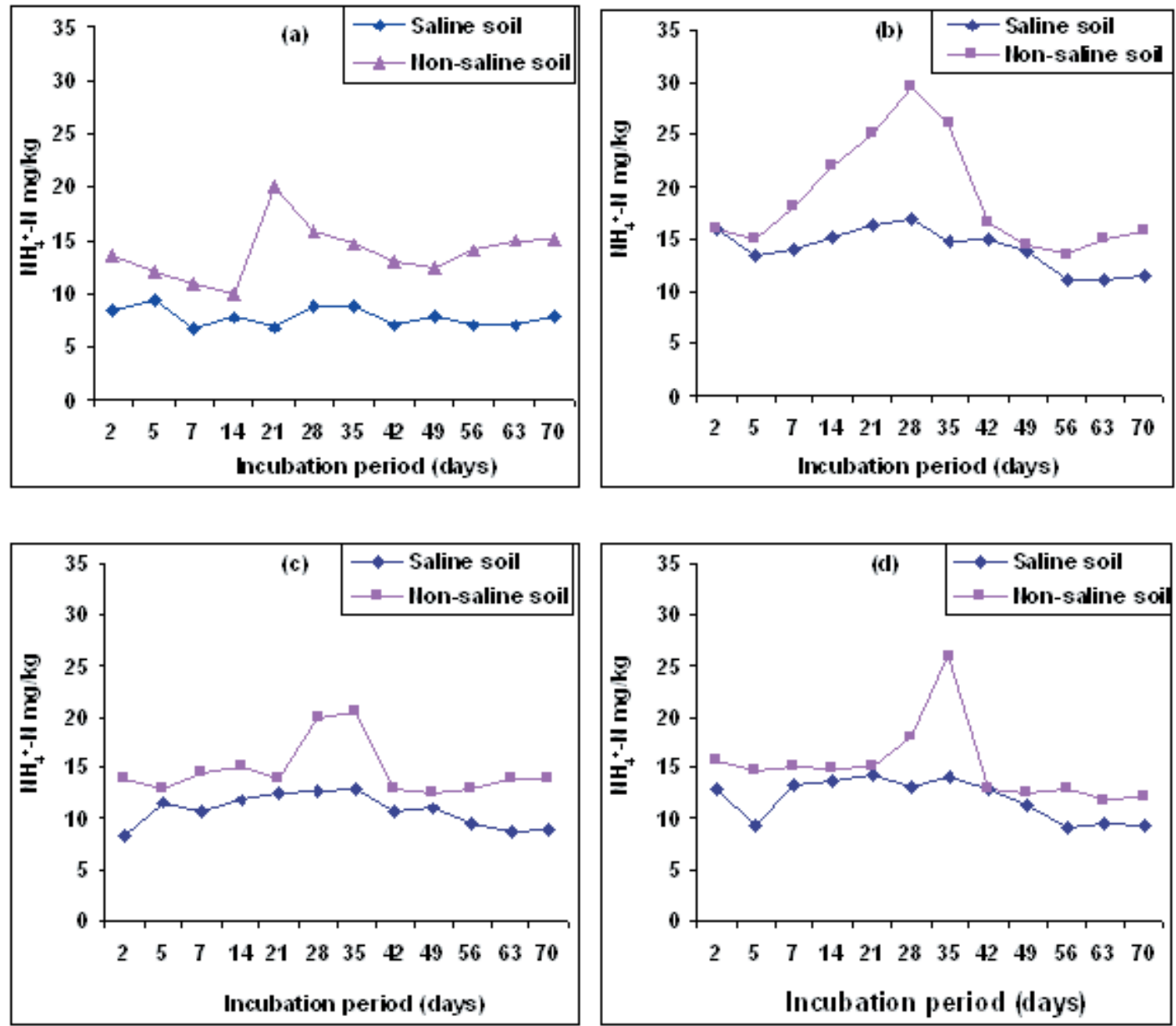

Fig. 3: Release of $\mathrm{NH}_{4}{ }^{+}-\mathrm{N}$ from saline and non-saline soils amended with different plant residues. (a), (b), (c) and (d) represent control (without plant residues), Sesbania, Caliandra and Gliricidia leaves, respectively. Values are the means $(n=4) \pm$ standard deviation 

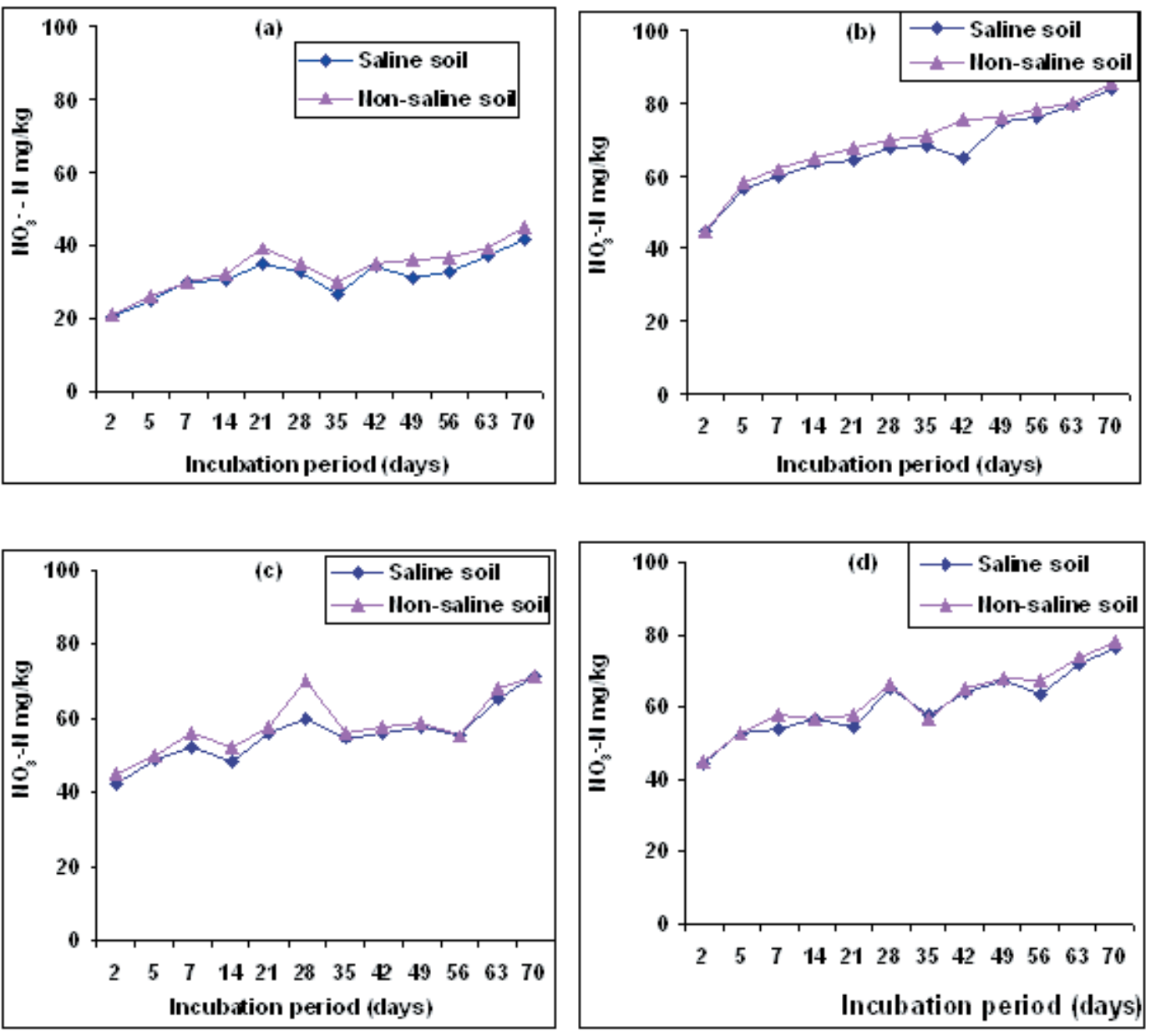

Fig. 4: Release of $\mathrm{NH}_{3}{ }^{-} \mathrm{N}$ from saline and non-saline soils amended with different plant residues. (a), (b), (c) and (d) represent control (without plant residues), Sesbania, Caliandra and Gliricidia leaves, respectively. Values are the means $(n=4) \pm$ standard deviation

decomposing process. However, according to Nourbakhsh and Dick (2005), the influence of the $\mathrm{C} / \mathrm{N}$ and lignin/ $\mathrm{N}$ ratios of the plant residues on the rate of $\mathrm{N}$ mineralization is not significant, but the net $\mathrm{N}$ mineralization potential is heavily depended upon the $\mathrm{N}$ content of plant residues. The conditions under which the present incubation took place were not favorable either for denitrification or leaching out nitrogen from the soil. Continuous increase in $\mathrm{NO}_{3}^{-}-\mathrm{N}$ content throughout the incubation is thus due to the nitrification process. Senanayake, (2004) has also reported similar results in nitrogen mineralization of these species. Similar nitrification pattern of $\mathrm{NH}_{4}{ }^{+}-\mathrm{N}$ to $\mathrm{NO}_{3}{ }^{-}-\mathrm{N}$ have also reported by Irshad et al., (2005) for saline soils.

\section{Conclusion}

Results could be concluded that the response pattern of $\mathrm{C}$ and $\mathrm{N}$ mineralization to salinity stress is depending upon the type of plant residue incorporated into the soil. The mineralization pattern was found to be varied with the time also. Studies under field conditions would provide better illustration as to how mineralization takes place in plant residue amended saline and non-saline soils.

\section{References}

Alef K. (1995). Soil Respiration. In: Methods in Applied Soil Microbiology and Biochemistry. Alef, K. (Ed.) (Academic Press, New York), pp. 214-222. 
Al Yassin A. (2005). Adverse effects of salinity on citrus. International Journal of Agricultural Biology, 4: 668680.

Anjum R., Ahmed A., Rahmatullah M., Jahangir M. and Yousif M. (2005). Effect of soil salinity/sodicity on the growth and yield of different varieties of cotton. International Journal of Agricultural Biology, 4: 606608.

Asmalodhi M., Arshad F. and Ssajjad M. H. (2009). Changes in mineral and mineralizable $\mathrm{N}$ of soil incubated at varying salinity, moisture and temperature regimes. Pakistan Journal of Botany, 41(2): 967-980.

Blackmore L. C., Searle P. L. and Daly B. K. (1987). Methods of Chemical Analysis of Soils. NZ Soil Bureau, Scientific Report 80, NZ Soil Bureau, Lower Hutt.

Bremner J. M. and Mulvaney C. S. (1982). Total nitrogen. In: Methods of Soil Analysis Part 2. Chemical and Microbiological Methods. 2nd Edition. A.L. Page (Ed.) (American Society of Agronomy), pp. 1149-1178.

Dick W. A. and Gregorich E.G. (2004). Developing and Maintaining Soil Organic Matter Levels. In: Managing Soil Quality, Challenges in Modern Agriculture. Schjonning, P. Elmholt, S. and Christensen, B. T. (Eds.), (CABI Publishing, Cambridge, MA, SA), pp.103-120.

Dick W. A. and Tabatabai M. A. (1977). An alkaline oxidation method for determination of total phosphorus in soils. Soil Sci. Soc. Am. J. 41: 511-514.

Elsharawy M. A. O., Elbordiny M. M. and Abdelwahed S. A. (2008). Improvement of a salt affected soil on Bahr ElBakar area using certain industrial byproducts: Effect on physical and chemical characteristics. Journal of Applied Sciences Research, 4(7): 839-846.

Galinski E. A. (1995). Osmoadaption in bacteria. $A d v$. Microb. Physiol., 37: 273-328.

Garcia C. (2000). Microbial activity in soils of SE Spain exposed to degradation and desertification processes. Strategies for their rehabilitation. In: Research and Perspectives of Soil Enzymology in Spain. Garcia, C. and Hernandez, M. T. (Eds.), (CEBASCSIC, Spain), pp: 93-143.
Irshad M., Honna T., Yamamoto S., Eneji A.E. and Yamasaki N. (2005). Nitrogen mineralization under saline conditions. Communications in Soil Science and Plant Analysis, 36 (11 and 12): 1681-1689.

Mafongoya P. L., Barak P. and Reed J. D. (2000). Carbon, nitrogen and phosphorus mineralization of tree leaves and manure. Biology and Fertility of Soils, 30(4): 298305.

Mapa R. B., Somssiri S. and Nagarajah S. (1999). Soils of the wet zone of Sri Lanka. Soil Science Society of Sri Lanka, pp. 23-92.

McGill W. B. and Figueiredo C. T. (1993). Total Nitrogen. In: M. R. Carter (eds.), Soil Sampling and Methods of Analysis. Cana. Soc. Soil Sci. Lewis Publishers, Boca Raton, FL. USA. pp 201-211.

Muhammad S., Müller T. and Joergensen R. G. (2005). Relationships between soil biological and other soil properties in saline and alkaline arable soils from the Pakistani Punjab. In: PhD dissertation of microbial use of organic substrates and maize growth, especially in saline and alkaline soils of the Pakistani Punjab. Muhammad, S. (Ed.), (Witzenhausen), pp. 48-71.

Nakhone L. N. and Tabatabai M. A. (2008). Nitrogen mineralization of leguminous crops in soils. Journal of Plant Nutrition and Soil Science, 171: 231-241.

Nelson D. W. and Sommers L. P. (1982). Total Carbon, Organic Carbon and Organic Matter. In: Methods of Soil Analysis, Part 2. Chemical and Microbiological Methods. 2nd Edition. A.L. Page, (Ed.), (American Society of Agronomy), pp. 539-579.

Nourbakhsh F. and Dick R. P. (2005). Net nitrogen mineralization or immobilization potential in a residue amended calcareous soils. Arid Land Research and Management, 19(4): 299-306.

Nourbakhsh F. and Hossein A. R. (2006). Plant residue quality influences the response of $\mathrm{N}$ mineralization to salinity. Archiv. Agron. Soil Sci., 52: 571-577.

Okur N. (2002). Response of soil biological and biochemical activity to salinization. Ege Üniv. Ziraat Fak. Derg., 39(1): 87-93. 
Oren A. (1999). Bioenergetic aspects of halophilism. Microbiol. Molecular. Biol. Rev., 63: 334-348.

Pathak H. and Rao D. L. N. (1998). Carbon and nitrogen mineralization from added organic matter in saline and alkali soils. Soil Biology and Biochemistry, 30(6): 695702 .

Rao D. L. N. and Pathak H. (1996). Ameliorative influence of organic matter on biological activity of salt affected soils. Arid Soil Research and Rehabilitation. 10: 311319.

Robertson F.

A. and Morgan W. C. (1995). Mineralization of C and $\mathrm{N}$ in organic materials as affected by duration of composting. Aust. J. Soil Res., 33: 511-524.

Rowell D. M., Prescott C. E. and Preston C. M. (2001). Decomposition and nitrogen mineralization from biosolids and other organic materials: Relationship with initial chemistry. Journal of Environmental Quality, 30: 1401-1410.

Sardinha M., Muller T., Schmeisky H. and Joergensen R. G. (2003). Microbial performance in soils along a salinity gradient under acidic conditions. Applied Soil Ecology, 23: $237-244$.

SAS Institute (1988). SAS/STAT user's guide, Release 6.03. SAS Institute, Cary, North Carolina, USA.
Searle P. L. (1984). The Berthelot or Indophenol reaction and its use in the analytical chemistry of nitrogen: a review, Analyst, 109: 549-568.

Senanayake A. P. (2004). Carbon and nitrogen mineralization and release of nutrients from five tropical tree legumes leaves decomposing in soil. BSc thesis, (Department of Soil Science, Faculty of Agriculture, University of Ruhuna), pp. 39.

Thuriès L., Pansu M., Larré-Larrouy M. C. and Feller C. (2002). Biochemical composition and mineralization kinetics of organic inputs in a sandy soil. Soil Biology and Biochemistry, 34(2): 239-250.

Tiessen H. and Moir, J. O. (1993). Total and organic carbon. In: M. R. Carter (eds.), Soil Sampling and Methods of Analysis. Cana. Soc. Soil Sci. Lewis Publishers, Boca Raton, FL. USA. pp 187-199.

Vanessa N. L., Wong S. B., Greene R., Murphy B. and Dala R. (2004). The effects of salinity and sodicity on soil carbon turnover. SuperSoil 2004: 3rd Australian New Zealand Soils Conference, 5 - 9 December 2004, University of Sydney, Australia.

Zahran H. H. (1997). Diversity, adaptation and activity of the bacterial flora in saline environments. Biol. Fertil. Soils., 25: 211-223.

Received: March 02, 2010;

Accepted : February 17, 2011 